\title{
Improved Methods for Isolating Active Chloroplast from Chilling-Sensitive Melon, Bell Pepper and Eggplant
}

\author{
Kazuo Ichimura, Shin-ichi Watanabe* and Masayuki Oda \\ National Research Institute of Vegetables, Omamental Plants and Tea. Ano, Mie 514-23
}

\begin{abstract}
Summary
When chilling sensitive plants are exposed to low temperature, photosynthetic activity is rapidly reduced. To investigate the biochemical mechanisms involved in chilling-induced reduction in photosynthetic activity of the chloroplast, it is necessary to isolate active chloroplasts in a coupled state. When chloroplasts were isolated from chilling-sensitive melon (Cucumis melo L.), bell pepper (Capsicum annu um L.), and eggplant (Solanum melongena L.) by the current, conventional method, active, coupled chloroplasts were not obtained from melon and bell pepper leaves. To improve the method for isolating active chloroplasts from these plants, sucrose as an osmoticant was replaced with $\mathrm{NaCl}$ and sorbitol in the grinding and suspension media, respectively; isoascorbate and EDTA were also added in the grinding medium. With these media, isolated, chilled chloroplasts had measurable electron transport rates, and sufficient coupling to investigate the site of inhibition of photochemical processes. Melon leaves exposed to $5{ }^{\circ} \mathrm{C}$ for $24 \mathrm{hr}$ under 100 $\mu \mathrm{mol} \cdot \mathrm{m}^{-2} \cdot \mathrm{s}^{-1}$ showed a much reduced photosynthetic rate at $25^{\circ} \mathrm{C}$, compared to unchilled leaves. Measurements of activity of chloroplasts isolated from chilled and unchilled leaves by the improved method revealed that the whole-chain electron transport rates were unaffected by chilling, whereas the extent of coupling was decreased. This result suggests that photophosphorylation would be involved in the inhibition of photosynthesis in chilled melon leaves. Thus, the improved method for isolating chloroplasts is applicable to study the inhibition site of photochemical reactions in chilling-sensitive melon, bell pepper, and eggplant.
\end{abstract}

\section{Introduction}

When plants of tropical or subtropical origin are exposed to low temperatures from $0{ }^{\circ} \mathrm{C}$ to about $15{ }^{\circ} \mathrm{C}$, they suffer a severe damage, because photosynthetic activity is rapidly reduced (Aoki et al., 1989; Hodgson et al., 1987; Hodgson and Raison, 1989; Long et al., 1983). Many studies have been conducted on the inhibition site of photochemical reactions in chloroplasts of chillingsensitive plants, such as cucumber (Garber, 1977; Hodgson and Raison, 1989; Peeler and Naylor, 1988; Shen et al., 1990; Terashima et al., 1989,

Received for publication 24 October 1994.

A part of this work was supported by Grants-in-Aid for STA fellowship from the Science and Technology Agency, Japan.

* Present address : Hokuriku Natl. Agr. Exp. Stn. Joetsu. Niigata 943-01
$1991 \mathrm{a}$, b); tomato (Kaniuga et al., 1978; Martin and Ort, 1982; Walker et al., 1991); pumpkin (Tyystjärvi et al., 1989); maize (Baker et al., 1983; Long et al., 1983; Ortiz-Lopez et al., 1990); and rice (Terashima et al., 1989). These studies have shown that the site of inhibition of photochemical processes in chloroplasts depends on the incident light intensity. Exposure to $1,000 \mu \mathrm{mol} \cdot \mathrm{m}^{-2} \cdot \mathrm{s}^{-1}$ severely inhibits photosystem II (Baker et al., 1983; Ortiz-Lopez et al., 1990; Tyystjärvi et al., 1989); the inhibition is ascribed to the inactivation and disappearance of D1 protein, which binds plastoquinone, the secondary acceptor in photosystem II (Kyle et al., 1984; Ohad et al., 1984). Under dark conditions, the oxygen evolution system is selectively inhibited (Kaniuga et al., 1978; Margulies and Jagendorf, 1960; Shen et al., 1990; Terashima et al., 1989). The inhibition has been attributed to dissociation of 14 - and 20-k Da pro- 
teins in thylakoid membrane, which play a regulatory role in the oxygen evolution (Shen et al., 1990). On the other hand, from 100 to $500 \mu$ $\mathrm{mol} \cdot \mathrm{m}^{-2} \cdot \mathrm{s}^{-1}$, photophosphorylation (Garber, 1977; Terashima et al., 1989, 1991 a, b) and photosystem I are inhibited (Terashima et al., 1994).

Melon, bell pepper and eggplant are chillingsensitive vegetables whose cultivation period in the open field is limited by low temperature, whereas cultivation under artificially heated greenhouse is limited by cost. Because of these problems, studies on the biochemical mechanism of chilling injury in these vegetables were undertaken, specifically to clarify the inhibition site of photochemical reactions because chloroplasts are sensitive to chilling. One of the most available methods for investigating photochemical reactions is to isolate active chloroplasts in a coupled state, and to measure their electron transport capacity. Isolation of active chloroplasts is usually difficult, except in plants such as spinach (Katoh, 1976 a). To our knowledge, isolation of active chloroplasts in a coupled state from melon, bell pepper and eggplant has not yet been reported.

In this study, we improved a method of chloroplast-isolation from melon, bell pepper, and eggplant and studied the inhibition site of photochemical reactions in chloroplasts in chilled melon.

\section{Materials and Methods}

\section{Plant material}

Seeds of melon (Cucumis melo L. cv. Andes), bell pepper (Capsicum annuum L. cv. Kyomidori), and eggplant (Solanum melongena L. cv. Senryo No. 2) were sown in pots and grown in a temperature controlled chamber, $25^{\circ} \mathrm{C}, 14 \mathrm{hr}$ light period/ 20 ${ }^{\circ} \mathrm{C}$, and $10 \mathrm{hr}$ dark period. Light intensity at plant height was about $300 \mu \mathrm{mol} \cdot \mathrm{m}^{-2} \cdot \mathrm{s}^{-1}$. After 3 weeks fully grown primary or secondary true leaves were used for the subsequent experiments.

Improved method for the isolation of active chloroplasts

Five $g$ of fresh leaves of fresh weight were excised, cut into $1 \mathrm{~cm}$ strips, and the strips ground for $10 \mathrm{sec}$ in $25 \mathrm{ml}$ of ice-cold $50 \mathrm{mM}$ Hepes- $\mathrm{KOH}$ ( $\mathrm{pH} 7.5$ ) that contained $0.4 \mathrm{M} \mathrm{NaCl}, 5 \mathrm{mM} \mathrm{MgCl}$, $1 \mathrm{mM} \mathrm{Na} \mathrm{NaDTA}_{2} 5 \mathrm{mM}$ sodium isoascorbate and $0.1 \%$ bovine serum albumin with an Ace homogenizer (Nihonseiki Kaisha Ltd, Tokyo). The homogenate was passed through 8 layers of gauze and the filtrate centrifuged at $500 \times \mathrm{g}$ for $3 \mathrm{~min}$. The resulting pellet was resuspended in $5 \mathrm{ml}$ of $50 \mathrm{mM}$ Hepes-KOH ( $\mathrm{pH} 7.5$ ) that contained $0.3 \mathrm{M}$ sorbitol, $10 \mathrm{mM} \mathrm{NaCl}$, and $5 \mathrm{mM} \mathrm{MgCl} 2$ and recentrifuged at $500 \times \mathrm{g}$ for $3 \mathrm{~min}$. The pellet was resuspended in $1 \mathrm{ml}$ of the second medium. These procedures were performed below $4{ }^{\circ} \mathrm{C}$. The final suspensions were stored on ice but they were used for the determination of electron transport rates within $1 \mathrm{hr}$.

The difference between the improved method as described above and the conventional method (Katoh, 1976 a, 1981) was that the latter consisted of : $50 \mathrm{mM}$ Hepes- $\mathrm{NaOH}(\mathrm{pH} 7.5$ ), $0.4 \mathrm{M}$ sucrose, $10 \mathrm{mM} \mathrm{NaCl}, 5 \mathrm{mM} \mathrm{MgCl}_{2}$ and $0.1 \%$ bovine serum albumin for the grinding and first resuspending medium; whereas the second resuspending medium consisted of $50 \mathrm{mM}$ Hepes- $\mathrm{NaOH}$ $(\mathrm{pH} 7.5), 0.4 \mathrm{M}$ sucrose, $10 \mathrm{mM} \mathrm{NaCl}$, and $5 \mathrm{mM}$ $\mathrm{MgCl}_{2}$.

Measurement of electron transport rates in chloroplasts

Electron transport rates were measured polarographically, using a Clark type oxygen electrode at an irradiance of $1,000 \mu \mathrm{mol} \cdot \mathrm{m}^{-2} \cdot \mathrm{s}^{-1}$ at $25{ }^{\circ} \mathrm{C}$. A basal reaction medium that contained $10 \mathrm{mM}$ $\mathrm{NaCl}, 2 \mathrm{mM} \mathrm{MgCl})_{2}$, and $50 \mathrm{mM}$ Tricine-KOH (pH 7.8) was supplemented with the following reagents: $0.1 \mathrm{mM}$ methyl viologen and $1 \mathrm{mM} \mathrm{NaN}_{3}$ for the whole-chain electron transport rate from $\mathrm{H}_{2} \mathrm{O}$ to methyl viologen; $1 \mathrm{mM} \mathrm{K} \mathrm{K}_{3} \mathrm{Fe}(\mathrm{CN})_{6}$ for the whole-chain electron transport rate from $\mathrm{H}_{2} \mathrm{O}$ to $\mathrm{K}_{3} \mathrm{Fe}(\mathrm{CN})_{6} ; 2 \mathrm{mM}$ ascorbate, $50 \mu \mathrm{M} 2$, 6-dichlorophenol indophenol, $10 \mu \mathrm{M} 3$ (3,4-dichlorophenyl)1 , 1-dimethylurea, $0.1 \mathrm{mM}$ methyl viologen, and 1 $\mathrm{mM} \mathrm{NaN}_{3}$ for photosystem I electron transport rate; $1 \mathrm{mM} \mathrm{K}_{3} \mathrm{Fe}(\mathrm{CN})_{6}$ and $0.5 \mathrm{mM}$ p-phenylene diamine for photosystem II electron transport rate. Ammonium chloride at $5 \mathrm{mM}$ or methylamine hydrochloride at $20 \mathrm{mM}$ was added to the reaction medium to uncouple the photophosphorylation.

\section{Determination of chlorophyll content in chloroplasts}

The isolated chloroplasts were suspended in $80 \%$ acetone. The suspensions were left in the dark for $30 \mathrm{~min}$ and then centrifuged. Chlorophyll concentrations in the supernatant were determined with the equation by Arnon (1949), using the 
absorbance of the supernatant at 645 and 663 $\mathrm{nm}$.

\section{Determination of photosynthetic rate in melon leaves}

Rates of photosynthetic oxygen evolution in leaf discs were measured at $25{ }^{\circ} \mathrm{C}$ with a leaf-disc oxygen-electrode system (Hansatech, Kings Lynn, U. K.) as reported by Delieu and Walker (1981) under $1,000 \mu \mathrm{mol}: \mathrm{m}^{-2} \cdot \mathrm{s}^{-1}$ and at a saturating concentration of $\mathrm{CO}_{2}$ (about $5 \%$ ).

\section{Chilling treatment of melon leaves}

Experimental leaves were detached from the plant and floated on water at $5{ }^{\circ} \mathrm{C}$ with the adaxial surfaces facing upwards under $100 \mu \mathrm{mol} \cdot \mathrm{m}^{-2} \cdot \mathrm{s}^{-1}$ for $24 \mathrm{hr}$, whereas the control leaves were floated on water at $26^{\circ} \mathrm{C}$ under the same light intensity.

\section{Results}

Improvement of methods for isolation of active chloroplasts from melon, bell pepper, and eggplant leaves

In general, to investigate the activity of photochemical reactions, the electron transport rates higher than $50 \mu \mathrm{mol} \cdot \mathrm{m}^{-2} \cdot \mathrm{s}^{-1}$ are desirable (Katoh, 1976 b; Okayama, 1983). Furthermore, it is recognized that the coupling state of chloro- plasts becomes higher as the ratio of the electron transport rate without uncouplers to that with uncouplers decreases (Peeler and Naylor, 1988). Tables 1 and 2 show the electron transport rates of isolated chloroplasts obtained by the conventional method. In eggplant, the electron transport rates were higher than $100 \mu \mathrm{mol} \mathrm{O}_{2} \cdot \mathrm{mg}$ chlorophyll ${ }^{-1} \cdot \mathrm{hr}^{-1}$. In addition, rates of photosystem I and II without uncouplers were about half of those with uncouplers. These results suggest that active, coupled chloroplasts were obtained from eggplant by the conventional method. However, in melon, all rates except that of photosystem I were lower than $50 \mu \mathrm{mol} \mathrm{O}_{2} \cdot \mathrm{mg}$ chlorophyll ${ }^{-1} \cdot \mathrm{hr}^{-1}$. In particular, the rate of the whole-chain electron transport from $\mathrm{H}_{2} \mathrm{O}$ to $\mathrm{K}_{3} \mathrm{Fe}(\mathrm{CN})_{6}$ was not detected. Furthermore, the extent of coupling was very low, indicating that isolated chloroplasts were uncoupled. In bell pepper, the measured rates, except those for photosystem II, were lower than $50 \mu \mathrm{mol} \mathrm{O}_{2} \cdot \mathrm{mg}$ chlorophyll ${ }^{-1} \cdot \mathrm{hr}^{-1}$ and the extent of coupling was very low. These results indicate that active chloroplasts with coupled state were not obtained from the melon and bell pepper leaves with the conventional isolation method.

To improve the chloroplast isolation method, we modified the conventional method by adding to the

Table 1. Whole-chain electron transport rates of chloroplasts isolated from melon, bell pepper and eggplant leaves by the conventional method.

\begin{tabular}{|c|c|c|c|c|c|c|}
\hline \multirow{3}{*}{ Species } & \multicolumn{3}{|c|}{$\mathrm{H}_{2} \mathrm{O} \rightarrow$ Methyl viologen } & \multicolumn{3}{|c|}{$\mathrm{H}_{2} \mathrm{O} \rightarrow \mathrm{K}_{3} \mathrm{Fe}(\mathrm{CN})_{6}$} \\
\hline & \multicolumn{2}{|c|}{ Uncoupler $^{2}$} & \multirow{2}{*}{$\begin{array}{l}-/+ \\
(\%)\end{array}$} & \multicolumn{2}{|c|}{ Uncoupler $^{2}$} & \multirow{2}{*}{$\begin{array}{c}-/+ \\
(\%)\end{array}$} \\
\hline & $\stackrel{+}{+}$ & $\left.\mathrm{l}^{-1} \cdot \mathrm{hr}^{-1}\right)$ & & $\stackrel{+}{\stackrel{+}{\left(\mu \mathrm{mol} \mathrm{O} \mathrm{O}_{2}\right.}}$ & $\left.\cdot \mathrm{mg} \mathrm{chl}^{-1} \cdot \mathrm{hr}^{-1}\right)$ & \\
\hline Melon & 22 & 21 & 95 & 0 & 0 & - \\
\hline Bell pepper & 3 & 6 & 200 & 43 & 46 & 107 \\
\hline Eggplant & 201 & 116 & 58 & 168 & 73 & 43 \\
\hline
\end{tabular}

Ammonium chloride.

Table 2. Electron transport rates of photosystem I and II of chloroplasts isolated by the conventional method from melon, bell pepper and eggplant leaves.

\begin{tabular}{|c|c|c|}
\hline Species & $\begin{array}{l}\text { Asc/DPIP } \rightarrow \text { Methyl viologen } \\
\text { (Photosystem I) } \\
\qquad\left(\mu \mathrm{mol} \mathrm{O}_{2} \cdot \mathrm{mg}\right.\end{array}$ & $\begin{array}{l}\mathrm{H}_{2} \mathrm{O} \rightarrow \mathrm{p} \text {-Phenylenediamine } \\
\left.\mathrm{hr}^{-1}\right)\end{array}$ \\
\hline Melon & 116 & 23 \\
\hline Bell pepper & 43 & 100 \\
\hline Eggplant & 254 & 118 \\
\hline
\end{tabular}


grinding medium, ascorbate, dithiothreitol, and polyvinylpolypyrrolidone (Garber, 1977; Hodgson and Raison, 1989; Kaniuga et al., 1978; Martin and Ort, 1982; Nolan, 1980). However, the chloroplasts isolated from melon and bell pepper leaves by using this modified grinding medium proved to be inactive. Peeler and Naylor (1988) showed with cucumber leaves that $\mathrm{NaCl}$ and $\mathrm{Na}_{2}$ EDTA are effective for isolating active chloroplasts. Terashima (1989) reported that adding $\mathrm{NaCl}$ to the grinding medium and sorbitol to the resuspending medium is effective for isolating chloroplasts from cucumber leaves. Thus, we added $\mathrm{NaCl}$ and $\mathrm{Na}_{2}$ EDTA to the grinding medium and sorbitol to the resuspending medium and determined the electron transport rates of chloroplasts. Tables 3 and 4 show that electron transport rates of chloroplasts isolated by the improved method were higher than $50 \mu \mathrm{mol} \mathrm{O} 2 \cdot \mathrm{mg}$ chlorophyll ${ }^{-1} \cdot \mathrm{hr}^{-1}$ in all vegetable species tested and that the extent of cou- pling of electron transport was also high in all leaves tested. These results reveal that the improved method is preferable for isolating active, coupled chloroplasts from chilling-sensitive melon and bell pepper.

Photosynthetic and electron transport rates of chilled leaves of melon

We tested if the improved method to isolate active chloroplasts is applicable to target the inhibition site of photochemical reactions in chilled melon leaves.

Leaf discs of melon taken from leaves chilled at $5{ }^{\circ} \mathrm{C}$ for $24 \mathrm{hr}$ showed $59 \%$ lower photosynthetic rate at $25{ }^{\circ} \mathrm{C}$ than did unchilled control leaf discs (Table 5).

A determination of electron transport rates of chloroplasts isolated by the improved method revealed that the whole-chain electron transport rates from $\mathrm{H}_{2} \mathrm{O}$ to both methyl viologen and potas-

Table 3. Whole-chain electron transport rates of chloroplasts isolated from melon, bell pepper and eggplant leaves by the improved method.

\begin{tabular}{|c|c|c|c|c|c|c|c|}
\hline \multirow{3}{*}{ Species } & & \multicolumn{3}{|c|}{$\mathrm{H}_{2} \mathrm{O} \rightarrow$ Methyl viologen } & \multicolumn{3}{|c|}{$\mathrm{H}_{2} \mathrm{O} \rightarrow \mathrm{K}_{3} \mathrm{Fe}(\mathrm{CN})_{6}$} \\
\hline & & \multicolumn{2}{|c|}{ Uncoupler $^{2}$} & \multirow{2}{*}{$\begin{array}{c}-/+ \\
(\%)\end{array}$} & \multicolumn{2}{|c|}{ Uncoupler $^{2}$} & \multirow{2}{*}{$\begin{array}{r}-/+ \\
(\%)\end{array}$} \\
\hline & & $\stackrel{+}{{ }_{\mu} \mathrm{mol} \mathrm{O}}$ & $\left.-{ }^{-1} \cdot h^{-1}\right)$ & & $\stackrel{+}{(\mu \mathrm{mol} \mathrm{O}}$ & $\left.-\overline{-} \cdot \mathrm{hr}^{-1}\right)$ & \\
\hline \multirow[t]{3}{*}{ Exp.1 } & Melon & 153 & 44 & 29 & 154 & 44 & 29 \\
\hline & Bell pepper & 109 & 34 & 31 & 74 & 36 & 49 \\
\hline & Eggplant & 150 & 64 & 43 & 158 & 69 & 44 \\
\hline \multirow[t]{3}{*}{ Exp.2 } & Melon & 194 & 40 & 21 & 188 & 35 & 19 \\
\hline & Bell pepper & 167 & 52 & 31 & 71 & 40 & 56 \\
\hline & Eggplant & 255 & 78 & 31 & 258 & 48 & 19 \\
\hline
\end{tabular}

zethylamine hydrochloride.

Table 4. Electron transport rates of photosystem I and II of chloroplasts isolated from melon. bell pepper and eggplant leaves by the improved method.

\begin{tabular}{|c|c|c|c|}
\hline & Species & $\begin{array}{l}\text { Asc/ DPIP } \rightarrow \text { Methyl viologen } \\
\text { (Photosystem I) } \\
\qquad\left(\mu \mathrm{mol} \mathrm{O}_{2} \cdot \mathrm{mg} \mathrm{chl}^{-1} \cdot \mathrm{hr}^{-1}\right)\end{array}$ & $\begin{array}{l}\mathrm{O} \rightarrow \mathrm{p}-\text { Phenylenediamine } \\
\text { (Photosystem I ) }\end{array}$ \\
\hline \multirow[t]{3}{*}{ Exp.1 } & Melon & 362 & 146 \\
\hline & Bell pepper & 270 & 105 \\
\hline & Eggplant & 377 & 142 \\
\hline \multirow[t]{3}{*}{ Exp.2 } & Melon & 454 & 153 \\
\hline & Bell pepper & 242 & 122 \\
\hline & Eggplant & 321 & 140 \\
\hline
\end{tabular}


sium ferricyanide were unaffected by the chilling treatment, when the uncoupler was absent in the reaction medium (Table 6). However, when the un. coupler was present, chloroplasts from chilled leaves showed about 2 -fold higher rates than did those from unchilled leaves. These results indicate that the chilling treatment affected the chloroplasts, reducing the degree of coupling of the electron transport system (Table 6).

\section{Discussion}

To obtain active chloroplasts with coupled state from melon and bell pepper leaves, $\mathrm{NaCl}$ and sorbitol are necessary in the grinding and resuspending medium, respectively. Peeler and Naylor (1988) also observed with cucumber that $\mathrm{NaCl}$ is needed to obtain active and coupled chloroplasts. Why these compounds are effective in isolating active chloroplasts remains unsolved.

Peeler and Naylor (1988) found that with cucumber leaves $25{ }^{\circ} \mathrm{C}$ was optimal to isolate chloroplasts in the coupled state. On the other hand, Terashima et al. (1989, 1991 a, b) obtained active, coupled chloroplasts from cucumber by isolating them at $4{ }^{\circ} \mathrm{C}$ or lower. This difference seems

Table 5. Effect of chilling on photosynthetic rate of melon leaves".

\begin{tabular}{lc}
\hline \hline Treatment & Photosynthetic rate $\left(\mu \mathrm{mol} \mathrm{O}_{2} \cdot \mathrm{m}^{-2} \cdot \mathrm{s}^{-1}\right)$ \\
\hline Control & 34.4 \\
Chilled & 14.0 \\
\hline
\end{tabular}

Values show the mean of duplicate experiments.

2 Detached leaves were floated on water at $5^{\circ} \mathrm{C}$ (chilled) or $26^{\circ} \mathrm{C}$ (control) under $100 \mu \mathrm{mol} \cdot \mathrm{m}^{-2} \cdot \mathrm{s}^{-1}$ for $24 \mathrm{hr}$, af ter which their photosynthetic rates were determined at $25^{\circ} \mathrm{C}$. to be caused by the different resuspending medium composition : Peeler and Naylor (1988) used $\mathrm{NaCl}$ as an osmoticant whereas Terashima et al. (1989) used sorbitol. In this study, we also were able to isolate active, coupled chloroplasts from melon and bell pepper leaves under cold conditions by using sorbitol in the resuspending medium.

Chloroplast is known to be very sensitive to various stresses such as freezing, heat, high light, and water stress. When plants were subjected to these, photosynthetic activity was greatly decreased (Aoki et al., 1988, 1989; Ludlow and Björkman, 1984; Smillie and Hetherington, 1983). The modified chloroplast isolation method in this study may be applicable to melon, bell pepper, and egglant subjected to various environmental stresses other than cold, and may serve to obtain a better understanding of chloroplast reactions to stresses.

It has been reported that photosynthesis is rapidly inactivated when chilling-sensitive plants are exposed to a low temperature (Aoki et al., 1989; Hodgson et al., 1987; Hodgson and Raison. 1989; Long et al., 1983). In this study, the photosynthetic rate of melon leaf discs was reduced greatly by keeping discs at $5{ }^{\circ} \mathrm{C}$ for $24 \mathrm{hr}$ prior to rate determination at $25^{\circ} \mathrm{C}$.

Studies at the molecular level of photosynthesis inhibition by chilling have revealed that the inhibition site of a photochemical reaction varies with light intensities to which chloroplasts are exposed before extraction. Photophosphorylation is inhibited in cucumber leaves exposed from 100 to $500 \mu \mathrm{mol} \cdot \mathrm{m}^{-2} \cdot \mathrm{s}^{-1}$ (Garber, 1977; Peeler and Naylor, 1988; Terashima et al., 1989, 1991 a, b). Terashima et al. (1989, 1991 a, b), who had investigated the mechanism of inhibition of photo-

Table 6. Effect of chilling on whole-chain electron rates isolated from melon leaves by the improved method.

\begin{tabular}{|c|c|c|c|c|c|c|}
\hline \multirow{3}{*}{ Treatment } & \multicolumn{3}{|c|}{$\mathrm{H}_{2} \mathrm{O} \rightarrow$ Methyl viologen } & \multicolumn{3}{|c|}{$\mathrm{H}_{2} \mathrm{O} \rightarrow \mathrm{K}_{3} \mathrm{Fe}(\mathrm{CN})_{6}$} \\
\hline & \multicolumn{2}{|c|}{ Uncoupler $^{2}$} & \multirow{2}{*}{$\begin{array}{c}-/+ \\
(\%)\end{array}$} & \multicolumn{2}{|l|}{ Uncoupler $^{2}$} & \multirow{2}{*}{$\begin{array}{r}-/+ \\
(\%)\end{array}$} \\
\hline & $\stackrel{+}{(\mu \mathrm{mol} \mathrm{O}}$ & $-1 \cdot h r^{-1)}$ & & $\stackrel{+}{\left(\mu \mathrm{mol} \mathrm{O}_{2} \cdot \mathrm{mg} \mathrm{chl}^{-}\right.}$ & $-1-$ & \\
\hline Control & 107 & 28 & 26 & 107 & 34 & 32 \\
\hline Chilled & 108 & 53 & 49 & 114 & 74 & 65 \\
\hline
\end{tabular}

Values were obtained by single experiment.

$z \quad$ Methylamine hydrochloride. 
phosphorylation in chilled cucumber leaves under moderate light intensity, found that $\mathrm{CF}_{1}$, a coupling factor between the electron transport and photophosphorylation and a component of ATPase proteins, became dissociated from thylakoid membranes, whereas in unchilled chloroplasts, $\mathrm{CF}_{1}$ is located on the stromal surface of the thylakoid membrane and connected to another coupling factor $\mathrm{CF}_{0}$ which is tightly associated to the membrane. In this study, the extent of coupling of chloroplasts was reduced by chilling the leaves under $100 \mu \mathrm{mol} \cdot \mathrm{m}^{-2} \cdot \mathrm{s}^{-1}$. This result and the above findings suggest that photophosohorylation could be involved in the inhibition of photosynthesis in chilled melon leaves.

\section{Literature Cited}

Aoki, S., M. Oda and K. Hosino. 1989. Varietal differences in chilling-induced depression of photosynthesis and leaf growth in cucumber seedlings. J. Japan. Soc. Hort. Sci. 58 : 173-179.

Aoki, S., M. Oda and M. Nagaoka. 1988. Chilling and heat sensitivities in cucumber seedlings measured by chlorophyll fluorescence. Bull. Natl. Res. Inst. Veg., Ornam. Plants \& Tea, Japan A $2: 81-92$.

Arnon, D. I. 1949. Copper enzymes in isolated chloroplasts : polyphenol oxidases in Beta vulgaris. Plant Physiol. $24: 1-15$.

Baker, N. R., T. M. East and S. P. Long. 1983. Chilling damage to photosynthesis in young Zea mays. 2 . Photochemical function of thylakoids in vivo. J. Exp. Bot. $34: 189-197$.

Delieu, T. and D. A. Walker. 1981. Polarographic measurement of photosynthetic $\mathrm{O}_{2}$ evolution by leaf discs. New Phytol. 89 : 165-175.

Garber, M. P. 1977. Effect of light and chilling temperatures on chilling-sensitive and chilling-resistant plants. Plant Physiol. 59 : 981-985.

Hodgson, R. A. J., G. R. Orr and J. K. Raison. 1987. Inhibition of photosynthesis by chilling in the light. Plant Sci. 49:75-79.

Hodgson, R. A. J. and J. K. Raison. 1989. Inhibition of photosynthesis by chilling in moderate light : a comparison of plants sensitive and insensitive to chilling. Planta $178: 545-552$.

Kaniuga, Z., B. Sochanowicz, J. Zabek and K. Krzysty. niak. 1978. Photosynthetic apparatus in chilling. sensitive plants. I. Reactivation of Hill reaction activity inhibited on the cold and dark storage of detached leaves and intact plants. Planta 140 : 1.21-128.

Katoh, S. 1976a. Chloroplast. p. 316-318. In : Japanese society of biochemistry (ed.). Methods in biochemistry. vol. 12. Energy metabolism and biological oxidation vol. 1. Tokyo Kagaku Dojin, Tokyo. (In Japanese).

Katoh, S. 1976 b. Electron transport. p. 368-379. In : Japanese society of biochemistry (ed.). Methods in biochemistry. vol. 12. Energy metabolism and biological oxidation vol. 1. Tokyo Kagaku Dojin, Tokyo. (In Japanese).

Katoh, S. 1981. Chloroplast. p. 251-255. In : S. Katoh, S. Miyachi and Y. Murata (eds.). Methods in photosynthesis research, Kyoritu Shuppan, Tokyo. (In Japanese).

Kyle, D. J., I. Ohad and C. J. Arntzen. 1984. Membrane protein damage and repair : Selective loss of a quinone-protein function in chloroplast membranes. Proc. Natl. Acad. Sci. USA 81 : 4070-4074.

Long, S. P., T. M. East and N. R. Baker. 1983. Chilling damage to photosynthesis in young Zea mays. 1 . Effects of light and temperature variation on photosynthetic $\mathrm{CO}_{2}$ assimilation. J. Exp. Bot. 34 : 177-188.

Ludlow, M. M. and O. Björkman. 1984. Paraheliotropic leaf movement in Siratro as a protective mechanism against drought-induced damage to primary photosynthetic reactions: damage by excessive light and heat. Planta 161:505-518.

Margulies, M. M. and A. T. Jagendorf. 1960. Effect of bean leaves on photosynthetic reaction of isolated chloroplasts. Arch. Biochem. Biophys. 90 : 176-183.

Martin, B. and D. R. Ort. 1982. Insensitivity of wateroxidation and photosystem II activity in tomato to chilling temperatures. Plant Physiol. 70 : 689-694.

Nolan, W. G. 1980. Effect of temperature on electron transport activities of isolated chloroplasts. Plant Physiol. $66: 234-237$.

Ohad, I., D. J. Kyle and C. J. Arntzen. 1984. Membrane protein damage and repair: Removal and replacement of inactivated 32-kilodalton polypeptides in chloroplast membranes. J. Cell Biol. $99: 481-485$.

Okayama, S. 1983. Hill reaction. p. 109-122. In : Committee of methods in experimental biology (ed.). Methods in experimental biology. vol. 17. Plant Physiology (III). Maruzen, Tokyo. (In Japanese).

Ortiz-Lopez, A., G. Y. Nie, D. R. Ort and N. R. Baker. 1990. The involvement of the photoinhibition of photosystem II and impaired membrane energization in the reduced quantum yield of carbon assimilation in chilled maize. Planta $181: 78-84$.

Peeler, T. C. and A. W. Naylor. 1988. A comparison of the effects of chilling on thylakoid electron transfer in pea (Pisum sativum L.) and cucumber (Cucumis sativus L.). Plant Physiol. 86: 147-151.

Shen, J. R., I. Terashima and S. Katoh. 1990. Cause for 
dark, chilling-induced inactivation of photosynthetic oxygen-evolving system in cucumber leaves. Plant Physiol. 93 : 1354-1357.

Smillie, R. and S. E. Hetherington. 1983. Stress toler ance and stress-induced injury in crop plants measured by chlorophyll fluorescence in vivo. Chill ing, freezing, ice cover, heat, and high light. Plant Physiol. 72 : 1043-1050.

Terashima, I., S. Funayama and K. Sonoike. 1994. The site of photoinhibition in leaves of Cucumis sativus L. at low temperature is photosystem I, not photo system II. Planta 193 : 300-306.

Terashima, I., L. K. Huang and C. B. Osmond. 1989. Effects of leaf chilling on thylakiod functions, measured at room temperature, in Cucumis sativus L. and Oryza sativa L. Plant Cell Physiol. 30 : 811-850.

Terashima, 1., Y. Kashino and S. Katoh. 1991 a. Expo sure of leaves of Cucumis sativus $\mathrm{L}$. to low temperatures in the light causes uncoupling of thylakoids. I. Studies with isolated thylakoids. Plant Cell Physiol. 32 : 1267-1274.

Terashima, I., K. Sonoike, T. Kawazu and S. Katoh. 1991 b. Exposure of leaves of Cucumis sativus L. to low temperatures in the light causes uncoupling of thylakoids. II. Non-destructive measurements with intact leaves. Plant Cell Physiol. 32 : $1275-1283$.

Tyystjärvi, E., J. Ovaska, P. Karunen and E. M. Aro. 1989. The nature of light-induced inhibition of photosystem II in pumpkin (Cucurbita pepo L.) leaves depends on temperature. Plant Physiol. 91 : 1069-1074

Walker, M. A., B. D. McKersie and K. P. Pauls. 1991. Effects of chilling on the biochemical and functional properties of thylakoid membranes. Plant Physiol. $97: 663-669$.

メロン,ピーマンおよびナスからの葉緑体単離法の改良

$$
\text { 市村一雄・渡逼慎一 } * \text {. 小田雅行 }
$$

野菜・茶業試験場 514-23 三重県安芸郡安濃町草生

\begin{abstract}
摘
要

低温感受性植物では，低温による光合成活性の阻害 が低温障害の重要な要因の一つであると考えられてい る。低温による光合成活性の阻害機構を解明するため には，活性が高く，共役した葉緑体を単離することが 必要である。代表的な低温感受性野菜であるメロン， ピーマンおよびナスから常法により菜緑体を単離した が，メロンおよびと゚ーマンからは電子伝達系活性が高 く共役した葉緑体を得ることができなかった，そこで， これらの植物から，葉緑体を単離する方法の改良を行 った。磨砕液抢よび彩濁液の浸透圧調節剤として $\mathrm{NaCl}$ およびソルビトールをそれぞれ用い，磨砕夜に

離した：その結果，いずれの植物においても，活性が 高く共役した葉緑体を単雖することができた。

メロン葉を $5{ }^{\circ} \mathrm{C}, 100 \mu \mathrm{mol} \cdot \mathrm{m}^{-2} \cdot \mathrm{s}^{-1}$ の条件下で 24 時間低温処理した後，常温における光合成活性と上述 の改良法により単離した葉緑体の電子伝達系活性を調

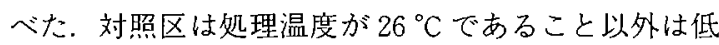
温処理区と同じ条件とした，光合成活性は低温処理に より対照の $41 \%$ まで減少した，電子伝達系活性に差 はみられなかったが，共役能は著しく滅少した。これ らの結果から，低温によるメロンの光合成活性阻害部 位は光リン酸化である可能性が示唆された。
\end{abstract} はイソアスコルビン酸とEDTA を加えて葉緑体を単

\footnotetext{
*現在：北陸些業試験場
} 